\title{
FREIGHT RATES AND TERMINAL SWITCHING
}

\section{SERVICES}

\section{By Charles S. Belsterling $\dagger$}

"At the present day every man has a fling at the uncertainty of the law. Yet, upon investigation it would appear that, in at least nine cases out of ten, the uncertainty complained of is not in the law, but in the facts to be applied. The law has sins enough of its own to answer for-defects sufficiently abundant-contradictions-doubts - even absurdities, which ought to be removed or remedied; but with all these, there are very few cases in which, if the facts were clearly ascertained, any respectable member of the profession could not, without hesitation, say what would be the law."

\section{William Morris Meredith}

The foregoing observations of the Honorable William Morris Meredith, ${ }^{1}$ for many years the leader of the old Bar of Philadelphia, apply with equal force today to the factual determinations of federal administrative agencies and commissions, to the end that "the event of litigation is indeed almost always uncertain." This uncertainty arises from the fact that the agency considers itself not bound by the rules of stare decisis and res adjudicata, and is not foreclosed by its earlier decisions. $^{2}$ Besides, administrators, as well as judges, do not all have the same temperament. The eight cardinal judicial virtues, as declared by Justice Shientag, ${ }^{3}$ are: independence, courtesy and patience, dignity, open-mindedness, impartiality, thoroughness and decisiveness, an understanding of heart, and indeed consciousness. "There is no guarantee of justice," said Professor Ehrlich, "except the personality of the judge." To use the "classic" words of Justice Holmes: "The life of the law has not been logic; it has been experience." 4

From an experience of many years in administrative procedure, it may truthfully be said that the Interstate Commerce Commission is one of the most outstanding and most efficient of the federal administrative agencies or commissions; it is generally recognized as a model for other

$\dagger$ Member of the Bars of Pennsylvania, New York, the Supreme Court of the United States, the United States Maritime Commission, and the Interstate Commerce Commission.

I. Adpresses Delivered in Commemoratton of the Centennial Celebration - Law Assoctation of Phinadeiphia 293 (1908).

2. Nebraska-Colorado Grain Products Ass'n., 243 I. C. C. 309, 336 (1940); see 3 Interstate CoMrMerce Acts ANN. I797 (I930).

3. Shientag, The Personality of the Judge (I944).

4. Shriver, Justice Oliver Wendell Holmes iI (I936). 
agencies. But, as in the case of such other agencies, its determinations and decisions have depended largely upon its findings of fact, which, until the Federal Administrative Procedure Act of $1946,{ }^{5}$ were not expressly required to be supported by "competent, credible and substantial" evidence. Such a lack of evidence requirements may explain the commission's holding, during the last decade, with a varying and "flexible" degree, "rather than a fixed standard," that the freight rates charged by the American railroads have not been designed to include the placement of cars upon the industrial spur tracks where they may be conveniently loaded or unloaded.

This holding, the result largely of hearings conducted in Ex parte No. 104, Part II, ${ }^{6}$ from I93I to 1935 , was made in contravention of numerous earlier decisions, reversed or ignored generally accepted principles of rate making, and failed to show that any new conditions have arisen which would justify such a reversal of policy. It is the purpose of this paper to review the formation and adoption of the original rate scheme by the commission to indicate the effect of the commission's findings in Ex parte No. I04, Part II, and then to review the cases in the light of and with due regard to the operation of the evidence requirements of the new Federal Administrative Procedure Act.

\section{Group or District Rates}

"Over seventy years ago, the American railroad rates were constructed on a group or district basis, originally applicable to the territory lying east of the Mississippi and north of the Ohio, and a definite amount of $\$$ r.20 per net ton was included therein to cover the terminal expenses at both ends of the haul."

Thus did Commissioner Harlan, of the Interstate Commerce Commission in 1909 in Saginaw Board of Trade v. Grand Trunk Railroad ${ }^{7}$ recognize the traditional and consistent basis of rate-making. This basis, the inclusion of terminal services in addition to the service of hauling the freight, is commonly known as the "McGraham Scale," and is even today the general foundation upon which rests the whole rate structure in the percentage basis territory. ${ }^{8}$ Thus, it has been emphasized by the entire shipping public and by the railroads themselves that, in this country, rates have been built to embrace the complete

5. Pub. L. No. 404, 79th Cong., 2d Sess. (June II, I946).

6. Ex Parte No. 104, Propriety of Operating Practices, Part II, Terminal Services, 209 I. C. C. II (I935).

7. I7 I. C. C. I28 (rgog).

8. Michigan Percentage Cases, 47 I. C. C. 409 (Igr7) ; see also Railroad Commission of Nevada, I9 I. C. C. 238 (I9I0) (involving a blanket rate group extending from the Rocky Mountains to the Atlantic), sustained, Intermountain Rate Cases, 234 U.S. 476 (rgi4) (commission has power to permit establishing zones by the railroads). See other cases cited I INTERstate Commerce ACTS ANN. 540 (I930). 
service from point to point, an emphasis warranted by the many judicial holdings that the expense of the two terminals and the line haul is included in the rate. ${ }^{9}$

The commission began to deal with the problems created in whole or in part by this scale in I9Io, beginning with the Five Per Cent Case, ${ }^{10}$ and developed a considerable body of cases relying thereon until the Eastern Class Rate Investigation in I930. ${ }^{11}$ Commissioner Harlan continued his recognition of the inclusion of terminal services in the group or district rate, in the Los Angeles Switching Case, ${ }^{12}$ in I9Io, Commissioners Lane and Prouty agreeing with this construction of the rate. As the former expressed it in the majority opinion, "The American Rate has always been recognized as carrying the full service which the carrier gives-in furnishing the car, a proper place at which to load it, the conveyance of that loaded car, and its terminal delivery." 13

\section{Section I5 (I3) Cases}

There was, therefore, apparent agreement that the carrier who performed terminal services was adequately compensated through payment of the ordinary rate by the shipper. A new problem arose when the shipper himself performed such services on his own spur tracks, with his own switch engines. Should he pay the full rate, or should he receive an allowance to compensate him for the costs he incurred by doing his own switching, "spotting" of cars for loading and unloading, and the like?

The Interstate Commerce Act spolke clearly enough on this problem in Section I5 (I3). ${ }^{14}$ "The Act in terms contemplates that if the carrier receives services from an owner of property transported, or uses instrumentalities furnished by the latter, he shall pay for them." 15 This obvious authorization to the carriers to make allowances to shippers who had performed their own terminal services was enacted upon

9. Board of Trade of Troy, 6 I. C. C. I23 (I893) ; Union Trust Co. v. Atchison, T. \& S. F. Ry., 64 Fed. 992 (N. D. Ill. I894), holding that a double charge for terminal service off line is unlawful, citing on 994 the opinion of Justice Harlan in Covington Stock-Yards Co. v. Keith, I39 U. S. I28 (I89r): "The carriage includes the delivery and there can be no delivery, except at such a place as is suitable to the delivery of the particular thing carried." In the Minnesota Rate Case, 230 U. S. 352, 384 (I913), Justice Hughes found that "Every rate contemplates two terminal charges, the initial and the final, and a haulage charge. It is declared to be a cardinal principle of rate making that . . the rate per ton mile should be less for the longer haul, as the terminal charges would be spread over a greater distance."

IO. 3 I I. C. C. 35 I (I9I4).

II. I64 I. C. C. 3 I4 (I930).

12. Associated Jobbers of Los Angeles, I8 I. C. C. 310, 324 (rgro).

I3. Id. at 3I4.

I4. 34 STAT. 590 (I906), 49 U. S. C. § I5(13) (1940).

I5. 3 InTERstate CoMmerce Acts AnN. 2037 (1930). 
the recommendation of President Theodore Roosevelt and of the commission, ${ }^{16}$ the latter pointing out in its I905 Annual Report that there are many instances in which the terminal services "can be rendered or the facilities furnished more advantageously both to shipper and railway and without injury to the public, if provided by the shipper himself." It would appear that no logical difficulty should result from an application of this provision in the presence of a recognition of the scope of the group or district rate as outlined above.

However, Commissioner Harlan, by a construction of the rate which contravened his findings as set forth in the Saginaze case, supra, sought by indirection to annul the allowances provisions of Section I5 (13) of the act. Without first making an equitable readjustment in the rates themselves, he drew an analogy in the Industrial Railways Case, rather imperfectly, to the English "conveyance rate" calling the American rates "line haul rates." 17 Since the English rate includes only the hauling of the car and excludes terminal services, ${ }^{18}$ this analogy would lead to the conclusion that the carrier had not been compensated for such terminal services. The inevitable result of such a misconstruction was to throw the rate scheme into confusion, and to lead Harlan to prohibit the carriers from making allowances to shippers as provided by the act.

In Allowances to Elevators, ${ }^{19}$ the Sugar Lighterage Case, ${ }^{20}$ and The Tap Line Case, ${ }^{21}$ Commissioner Harlan had attempted to apply his revolutionary principle of rate-making, declaring unlawful certain carrier allowances to shippers. In each case, the Supreme Court, recognizing the full scope of the group or district rate, rejected Harlan's construction of the rate and permitted such allowances. ${ }^{22}$ At the same time, the Court restricted the jurisdiction of the commission under Section I5 (I3) to a determination of the maximum allowance payable, prohibiting the commission from declaring any allowances completely unlawful.

16. 40 Cong. Rec. 92 (Ig05) ; 55 I. C. C. General Letter Book 52 (1905-I906).

17. Industrial Railways Case, 29 I. C. C. 2 I2 (Igr4).

I8. Simonds \& Sons v. Great Northern Ry., 3 Boyle \& Waghorn I7 (rgoo); North Staffordshire Ry. v. Salt Union Ltd., ro Ry. \& Ca. Tr. Cases I6r (I898) ; Tennant \& Co. v. The Caledonian Ry., Io Ry. \& Ca. Tr. Cases I94 (I898) ; Lancashire \& Yorkshire Ry. v. Gidlow, L. R. 7 H. L. 5I7 (I875); see also Vickers Sons v. Midland Ry., it Ry. \& Ca. Tr. Cases 249, 255 (Igor) ; Cockburn, The Law of Private Stdings and Private Traders (Ig09).

19. Io I. C. C. 309 (1904), I4 I. C. C. 315 (I908).

20. Federal Sugar Refining Co., 20 I. C. C. 200 (Igro); see also Federal Sugar Refining Co., I7 I. C. C. 40 (I909).

2I. 23 I. C. C. 277 (1912).

22. Interstate Commerce Commission v. Diffenbaugh, 222 U. S. 42 (I9II) ; United States v. Baltimore \& Ohio R. R., 23I U. S. 274 (I9I3); The Tap Line Cases, 234 U. S. I (IgI4). 


\section{Plant Facility Cases}

A further analogy was resorted to by Commissioner Harlan to negative the effect of Section I5 (13) by a construction of the group or district rates which would exclude terminal services from their comprehension. This was the analogy of the common carrier industrial railway to a "tool of the industry," ${ }^{23}$ or as expressed in the Industrial Railways Case, to a "plant smoke stack." 24 On the theory that the carrier was obligated, under existing rates, to deliver the car only as far as the interchange track at industrial shipper's plant, it was reasoned that services performed on tracks which were a part of the "plant facility" could not have been comprehended by the rates. If the shipper performed such services on a "plant facility," the carrier had not been paid for something he was otherwise obligated to do, and allowances to the shipper by the carrier were thought to be unlawful.

This, at any rate, was the theory employed by Commissioner Harlan in the General Electric case, ${ }^{25}$ the Manufacturers Railway case, ${ }^{26}$ and the Industrial Railways Case. ${ }^{27}$ The commission did not adopt the theory. As Commissioner Meyer pointed out in Car Spotting Charges, 28 "spotting service [the placing of the car upon the industrial shipper's tracks for loading and unloading without regard to the size or complexity of the industry-one of the terminal services] is covered by the carriers' rates as determined by the general usage." The General Electric case, he stated, did not require the commission to determine whether the carriers could be called upon to make deliveries through a network of interior switching tracks, but that "the point actually decided was that the complainant was not entitled to an allowance from the carrier for a service which the carrier was ready and willing to perform . . . because it was not convenient for it to permit the carrier to perform the service."

The Mamifacturers Railway case was later modified by the commission. ${ }^{29}$ Harlan's holding in the case was not a strong one, since it relied largely upon the General Electric case, explained away, as we have seen, in Car Spotting Charges, and upon the Crane Railroad case. $^{30}$ This latter, the product of the same thinking in terms of "plant facility" was decided by the Commerce Court, but its vitality

23. General Electric Co., I4 I. C. C. 237 (1908). See Tap Line Case, 23 I. C. C. 549 (I9I2), rev'd, 234 U. S. I (rgI4).

24. 29 I. C. C. 212,224 (I9I4), rev'd, 32 I. C. C. I29 (I9I4).

25. General Electric Co., I4 I. C. C. 237 (I908).

26. Manufacturers Ry., 28 I. C. C. 93 (I9r3).

27. 29 I. C. C. $2 \mathrm{I} 2$ (I9I4).

28. 34 I. C. C. 609,617 (1915).

29. Manufacturers Ry., 32 I. C. C. Ioo (I9I4).

30. Crane Iron Works v. United States, 209 Fed. 238 (Comm. Ct. Igr2). 
as a precedent was destroyed by the Supreme Court's finding that the court acted without jurisdiction to determine the matter. In fact, both the Public Service Commission ${ }^{31}$ and the Supreme Court of Pennsylvania, ${ }^{32}$ in handling the problem of the Crane Railroad, followed the laws of the state as well as the Supreme Court ruling, rejecting the Commerce Court's "regarding the Crane Railroad as a plant facility for the proprietary company." They found the railroad to be a bona fide common carrier and entitled to all rights as such, i. e., allowances from the main carrier for performing terminal services for the proprietary company.

The third case cited above in which Commissioner Harlan attempted to alter the application of group or district rates, the Industrial Railways Case ${ }^{33}$ was also short lived in its effect. The Supreme Court, in The Tap Line Cases, ${ }^{34}$ reversed a similar ruling shortly thereafter. The commission itself, in the Second Industrial Railways Case, ${ }^{35}$ reversed Harlan's prior decision. Further, the state commissions, handling the same problem in intra-state traffic, refused to permit rail carriers to demand extra compensation for performing terminal services." As stated by the Pennsylvania commission: "The complainants are entitled to placement of cars as part of the transportation service. The railroads must, under the disclosed circumstances, employ the incorporated railroads and make allowances to them out of the line haul rates. They may employ the railroad facilities of the plant industries where the railroads are not incorporated, in which event the trunk lines must make similar allowances." 37

One other attempt was made by Harlan to divorce terminal services from the rate. In the Iron Ore Rate Cases, ${ }^{38}$ he evolved a novel method of splitting the rates on iron ore from the lower Lake Erie ports to the blast furnaces in Ohio, West Virginia, and the western part of Pennsylvania, and required the carrier to make an added charge for spotting the cars for unloading. This added charge was assessed

3r. National Tube Co. v. Baltimore \& Ohio R. R., I9I9C P. U. R. 4 I8 et seq. (I9I9). The Pennsylvania commission, discussing the last unsucessful attempt of Commissioner Harlan to restrict the rates of rail carriers to points of interchange, stated that such a method, "if followed ... would again throw the whole industrial railway administrative policy into a chaos of incertitude from which it was theretofore rapidly and happily emerging." (p. 435)

32. Crane R. R. v. Central R. R. of New Jersey, 248 Pa. 333, 93 Atl. Ioz6 (Igr5).

33. 29 I. C. C. 212 (I914).

34. 234 U. S. I (I9I4).

35. 34 I. C. C. 596 (Ig15). See also 32 I. C. C. I29 (I914);

36. Elwood, A. \& L. P. R. R. Case, Ind. Pub. Serv. Comm'n., Docket No. 23ro (I9I7) ; Discontinuance of Allowances, N. Y. Pub. Serv. Comm'n., 2d Dist., Case No. 2152 (IgI4); Lake Terminal R. R. v. Ann Arbor R. R., Ohio Pub. Serv. Comm'n., Docket No. I87 (July I, I9I4).

37. Monongahela Connecting R. R. v. Pittsburgh \& L. E. R. R. et al., Pa. Pub. Serv. Comm'n., Complaint Docket No. I93-2 (I9I4).

38. 4 I I. C. C. I8I (I916), 44 I. C. C. 386 (I917). 
notwithstanding the fact that the terminal delivery of iron ore is the most economical delivery service rendered in interstate commerce. These cases are isolated, and have not been cited as authority in connection with rates for any other commodity. In I937, the commission itself, in General Commodity Rate Increases, ${ }^{39}$ found the holding inconsistent with the well-settled comprehension of group or district rates and declared the rule no longer in effect.

One other isolated case during this period is the decision of Judge Cardozo in the General Electric case before the Court of Appeals of New York. ${ }^{40}$ Reversing an Appellate Division ruling, he stated that it was not customary for the railroad to haul cars further over an intricate system of tracks and found payment to the shipper by the carrier unlawful in spite of Section I5 (I3). His conclusion that the rule established was "in harmony with the prevailing practice in England and Germany" runs counter to the findings of the commission in Car Spotting Charges ${ }^{41}$ and in the Los Angeles Switching Case, ${ }^{42}$ and was, it is asserted with the greatest respect, the result of confusion engendered by. Commissioner Harlan's imperfect analogy of the pseudotechnical phrase, line haul rate, with the English conveyance rate. The ruling was so diametrically opposed to the fundamental principles of American rate making, that it was disregarded as a precedent by the Interstate Commerce Commission and by the federal courts, except in one case ${ }^{43}$ which was itself later overruled. ${ }^{44}$

It is thus apparent that, despite the confusion which crept into the American rate scheme by reason of fallacious analogies such as the "line haul rate" and the theory of "plant facility," the commission, the Supreme Court of the United States, and the state courts and commissions recognized clearly enough the fact that the group or district rate, of long standing, had been designed to include the entire service of hauling and delivery, while it was further recognized that any performance of part of such service by the shipper should receive compensation through an allowance from the carrier.

\section{Industrial RaIlways Provisions of the ACT}

A further hurdle to the payment of allowances to shippers was presented by the commodities clause of the act. ${ }^{45}$ The commission, in

39. 223 I. C. C. 657 (I937).

40. New York Central \& H. R. R. R. v. General Electric Co., 2Ig N. Y. 227, Ir4 N. E. II5 (IgI6).

4I. 34 I. C. C. 609 (I9I5). (I9I4)

42. Associated Jobbers of Los Angeles, I8 I. C. C. 3Io (Igro), aff'd, 234 U. S. 284

43. The Lake Terminal Case, 50 I. C. C. 489 (Igr8).

44. National Tube Co., 55 I. C. C. 469 (IgI9).

45. 34 Stat. 585 (Ig06), 49 U. S. C. \& I (8) (I940). 
I9I0, had defined an industrial railway "as an unincorporated or incorporated railway controlled by some manufacturing or mining industry, the major portion of whose traffic is furnished by the controlling company." 46 It has been settled by a multiplicity of cases, however, that the amendment to the act embodied in Section I5 (13) was phrased by the commission itself in the 1905 recommendations to Congress for the express purpose of fixing the commission's jurisdiction to determine the maximum allowance to such industrial common carriers affiliated by stock ownership with the shipper. ${ }^{47}$ That "the transportation in interstate commerce by a corporation whose stock is owned by an industrial corporation of commodities produced or owned by such corporation is not a violation of the commodities clause of said interstate commerce act, but is sanctioned by and subject to regulation under Section I5 (I3) of said interstate commerce act," was found by the federal court for Southern Illinois in $1935 .{ }^{48}$ As pointed out by Justice McReynolds in affirming ${ }^{49}$ the Elgin case, Section I (8) of the act, commonly known as the commodities clause, had remained unchanged for some thirty years and "we must therefore conclude that the interpretation then accepted has legislative approval." To hold that industrial short lines, of which there are some 300 in the country, are not protected by Sections I5 (I3) and I (9) of the act, to hold that the ownership and operation of such lines fall within the purview of the commodities clause, Section I (8), and that allowances by carriers to shippers, owners of such lines, are for that reason unlawful, would be "judicial legislation" running counter to an enormous body of precedents as well as to legislative approval. ${ }^{50}$ The avowed purpose of Section I (9) of the Act, as clearly shown by its legislative history, was to insure the owners of industrial branch or lateral lines of railroads prompt switch connections with the long line carriers and fair and reasonable prorating arrangements with them.

\section{Ex Parte No. I04, Part II}

Against such a background of recognition of the group or district rate and of approval of payments to shippers for performance of terminal services, the action of the commission in the proceeding styled $E x$

46. Twenty-Fourth Annual Report of the Interstate Commerce CommisSION 35 (IgI0).

47. O'Keefe v. United States, 240 U. S. 294 (I9I5) ; The Tap Line Cases, 234 U. S. I (I914); National Malleable Castings Co., 5I I. C. C. 537 (rgI8). See also I905 recommendations made to Congress by President Theodore Roosevelt: "The owners of industrial railroads are entitled to a fair and reasonable compensation on their investment."

48. United States v. Elgin, J. \& E. Ry., II F. Supp. 435 (N. D. I11. I935).

49. United States v. Elgin, J. \& E. Ry., 298 U. S. 492 (I936).

50. Belsterling, Legislative History of the Comratodities Clause of the INterstate CoMmrerce ACT 150 et seq. (1945). 
Parte No. IO4, ${ }^{51}$ was a distinct reversal of policy. Although there was no complaint or dissatisfaction, either among the shippers or carriers, with the then existing practices, the commission, in considering Sections I2 and 15 (a) of the act, entered into an investigation on its own motion of the practices by railroads affecting operating revenues or expenses. This investigation fell into two parts. Part II covered the two questions which have formed the body of this paper up to this point: (a) terminal transportation services performed on industry sidings in placement of cars at convenient places for loading or unloading, $i$. e., "spotting", and (b) the lawfulness of any allowances made to industries for the performance of such "spotting" services.

Alfred G. Haggerty and Riley A. Gwynn, special counsel for the commission, recommended upon brief an ultimate finding that "there is little, if anything, wrong with the present practices of carriers in rendering these spotting services or in paying industries reasonable compensation for performing them." "Certainly," said counsel, "they have not been proven burdensome against the railway operating revenues or operating expenses." 52

The commission did not so find. In fact, Officer Bartel, presiding at the hearings, suggested that the commission should recommend to Congress the repeal of Section $x_{5}$ ( $x_{3}$ ), under which it had been clearly and well established that the commission was without power to prohibit entirely allowances for spotting services. ${ }^{53}$ Officer Bardwell, who also presided, did not publish a proposed report, and the presumption is that he either disagreed with Officer Bartel's proposal or did not concur in it. The result was a compromise whereby the commission did not issue a single omnibus report but decided to dispose of the various cases singly.

Seventy-eight supplementary reports were issued following the original opinion in Ex parte No. 104, Part II of May I4, 1935. Over seventy per cent of these reports prohibited entirely the payment of allowances under Section $\mathrm{I}_{5}$ ( $\mathrm{x} 3$ ), allowances which had been expressly authorized by prior orders of the commission. Of the remaining thirty per cent of the reports, a number originally held the allowances to be unlawful, though the findings were modified within five to ten years thereafter.

51. Ex Parte No. 104, Propriety of Operating Practices, Part II, Terminal Services, 200ं I. C. C. II (I935). 1933).

52. Brief filed by Alfred G. Haggerty and Riley A. Gwynn, pp. 44-45 (Jan. 3,

53. United States v. Baltimore and Ohio R. R., 23I U. S. 274 (1913) ; Interstate Commerce Commission v. Louisville and Nashville R. R., 227 U. S. 88 (I9I3) ; Interstate Commerce Commission v. Diffenbaugh, 222 U. S. 42 (I9II); Southern Pacific Co. v. Interstate Commerce Commission, 2I9 U. S. 433 (IgII) ; Interstate Commerce Commission v. Northern Pacific Ry., 216 U. S. 538 (I9I0) ; Interstate Commerce Commission v. Stickney, 215 U. S. 98 (Ig09); Lighterage Cases, 203 I. C. C. 48 I (1934). 
It is significant, therefore, in the light of the commission's previous declaration that "the rates ought to be fixed high enough to warrant the carriers including the spur track service without extra charge and not on the theory that additional revenue be available from that source," ${ }^{54}$ that there was no inquiry made in the proceedings under discussion to determine whether the particular rates being investigated were fixed high enough to cover the complete transportation services customarily involved. It is asserted that these reports represent a change of policy running counter to a multitude of the precedents discussed heretofore, to the fundamental principles of rate making, and to the facts of many a particular case.

The Allegheny Steel Company situation ${ }^{55}$ serves as an example of the cases wherein the commission, as a result of these proceedings, prohibited carrier allowances on a record barren of any competent or credible evidence in support of a finding that group rates do not cover the cost of completing the spotting service. The plant of the company is located in Pennsylvania, where the obligation of the carrier in intrastate traffic to render the spotting service is well settled: such as classifying cars in the yards of the industries according to the materials with which they are to be loaded and placing them at the customary places for loading or unloading, without additional charge. ${ }^{56}$. The allowance in interstate traffic had previously been published pursuant to an order of the commission. The existing rates had clearly been established to include these terminal services, since the commission, in setting up steel rates in Docket I7000, Part 6, had formerly declared that "grouping of the original and destination points involved have been more or less general." ${ }^{57}$ The record, in the investigation which later disallowed such carrier payments, carries, in fact, the uncontradicted statement of Julian Eysmans, Vice President-Traffic, the Pennsylvania Railroad, which serves the Allegheny plant, that "from the very beginning freight rates have been made with the definite idea that the spotting service is included in the rate."

The conclusion arrived at in the vast majority of the supplementary reports, that the compensation of an owner of transported property, or the use of instrumentalities furnished by the shipper, violated

54. Associated Jobbers of Los Angeles, I8 I. C. C. 3ro (I910).

55. Allegheny Steel Co. Terminal Allowance, 209 I. C. C. 273 (1935).

56. National Tube Co. v. Baltimore \& Ohio R. R., I9I9C P. U. R. 4I8 (I9I9); see also \$ I, Transportation Act of 1940: "It is hereby declared to be the national transportation policy of the Congress to provide for fair and impartial regulation of all modes of transportation subject to the provisions of this Act, so administered . . . to cooperate with the several States and the duly authorized officials thereof. . . " 54 STAT. 899, 49 U. S. C. \$ 428 I (I940). (I929).

57. Rate Structure Investigation-Iron and Steel Articles, I55 I. C. C. 5I7, 533 
Section 6 (7) of the act, is difficult to understand in the light of the commission's ruling otherwise, as far back as the Los Angeles Switching Case, wherein Commissioner Lane had stated: "The provisions of the Act to regulate commerce were enacted with respect to the American method of stating rates . . . terminal charges referred to, in section 6, and which must be expressly set forth in the carrier's tariff, are those for other services at the terminal which the carrier may furnish, such as storage, elevation, switching, and cartage. This construction of the Act is borne out fully by its history and has been formally accepted by railroad counsel in advising the carriers." 58 (Emphasis supplied.)

The Riter-Conley situation ${ }^{58}$ is cited in the original report of $E x$ parte No. I04, Part II to support the finding that payment by the shipper for spotting, rather than conceiving the spotting as included in the group rate, enables the industry to secure a superior and preferential service. Again, as in the Allegheny case, it should be pointed out that structural steel, the commodity there involved, is unquestionably bearing freight rates appreciably higher than other rates, certainly high enough to cover the expense of the complete terminal spotting service.

The Downey Ship Building case ${ }^{60}$ is cited in the same report as authority for restricting the coverage of the New York group rates on finished steel articles to the point of interchange between the rails of the main carriers and the plant tracks. The commission had previously refused to split the New York Harbor rates into line haul and terminal delivery, instead fixing the group rate to cover the entire harbor service, including floating and lighterage. A holding that a shipper must perform his own spotting services, a narrow part of the entire terminal service, at his own expense, or a finding that the mere placement of a car for unloading on an industry track on Staten Island is a greater service than the other services involved, could not, it should be asserted, have been supported by any reliable, probative, and substantial evidence.

Another rule now employed by the commission to restrict rates to interchange points is the use of a theory of "interference." Where 284 (I9I4).

58. Associated Jobbers of Los Angeles, I8 I. C. C. 310, 315 (I9I0), aff'd, 234 U. S.

59. Riter-Conley Manufacturing Co., 58 I. C. C. 327 (I920). See also preliminary statistics on file with Interstate Commerce Commission for calendar year I945:Average car mile earnings on all traffic-3I.I7 cents.

Average haul on all traffic-282.6 miles.

Average car mile earnings on finished steel articles for average haul of 282.6 miles-95 cents.

Average load of finished steel articles -40.8 tons.

6o. Downey Ship Building Corp., 60 I. C. C. 543 (I92I) ; see also The New York Harbor Case, 47 I. C. C. 643, 712 (I9r7): "The practice of embracing many points within the same group or zone has been so generally adopted by the carriers and so frequently recognized as proper by this Commission that its general propriety can hardly be challenged." See I INTERSTATE COMMERCE ACTS ANN. 40 et seq. (I930) for numerous cases cited in support of this proposition. 
car deliveries are prevented by interferences incidental to all terminal services, the commission now holds that the obligation of the carrier under its so-called line haul ends by merely shunting a drag of unclassified cars upon an interchange track. This obligation is measured by "simple switching on team tracks," said in the Corn Products Case to be a flexible guide rather than a fixed standard. ${ }^{61}$ The plant of the Corn Products Company is located in the Chicago switching district, however, the law concerning the rates of that area having been clearly expounded in the Chicago Switching District case: ${ }^{62}$ "For each rate a carrier offers and obligates itself to perform a certain amount of service. If the service so offered and for a long time performed in consideration of that rate includes taking the property transported from a given point . . . the delivery at that point is in no sense a 'free service." " In the Corn Products Case, counsel offered to prove that the terminal switching service customarily performed within the Chicago switching district is obviously much greater service than that involved in placing cars within the plant of the Products Company ( $R$. I460). That the ruling of the commission in the Corn Products Case did not go completely unchallenged is witnessed by the dissenting opinion entered in the 1946 opinion in that case, which pointed out that "the majority declares unlawful a tariff which had been lawfully filed with the Commission and has the force of statute."

Another significant restriction upon the payment of allowances by carrier to shipper came as a result of the commission's fifth supplemental report of May I4, $1935{ }^{63}$ where the commission held that two carriers serving one plant had complied with obligations under the interstate "line haul rate" by delivery and receipt of carload freight on interchange tracks of the industry and that the payment of allowances for service performed by the industry beyond that point was unlawful in violation of Section 6 (7) of the act, in spite of the fact that the payment had been lawfully covered by published tariffs. A series of rehearings resulted in a modification of this finding in $1946,{ }^{64}$ whereby the commission now holds that, only after the plant has been separated into two parts for spotting services, to be served separately by the two rail carriers, can the spotting services involved fairly be regarded as contemplated under the line haul rates. In other words, as a condition precedent to an industry's being entitled to the prevailing group or district rates, it must be served exclusively by one rail carrier.

6r. Corn Products Refining Co. Terminal Service, 262 I. C. C. 57 (I945), 266 I. C. C. I8I (I946).

62. 34 I. C. C. 234 (I9I5).

63. Standard Oil Co. of Louisiana Terminal Allowance, 209 I. C. C. 68 (I935).

64. 266 I. C. C. 437 (I946). 
As a result, therefore, of the findings in Ex parte No. I04, Part II and of the supplemental reports stemming therefrom, in the absence of a clear showing that conditions have actually warranted such findings, the shipping industry has been compelled to relieve the carriers from the performance of terminal services for which these carriers have been paid in their rates. For many years such a practice has been characterized as the imposition of a double charge and unlawful as such. To paraphrase Commissioner Prouty in the Los Angeles Szeitching Case ${ }^{65}$ the carrier has been charging over a period of eleven years since this drastic reversal of policy, for a service which has cost it nothing.

A strong dissenting opinion was filed by Commissioner Mahaffie to the commission's original report in Ex parte No. IO4, Part II. Among other things, Commissioner Mahaffie strongly urged that the majority had not made a finding that spotting services for which carriers had been making allowances had not previously been considered in fixing the level of the rates. The record, he stated, conclusively indicated that, in many instances, such services had in fact been considered by the commission in the past. Equally conclusive was the evidence in the record that it is generally an economy to the carrier to make the allowance rather than perform the service, or, because of the volume of traffic and lack of capital investment in the facility and the expense of maintaining it, that it is at least less expensive to the carrier to perform terminal services on industry tracks than on its own team tracks. Differing from the majority of the commission, he asserted that placement of cars on industry tracks is as much a carrier's duty as placement of cars on its own team tracks. ${ }^{65 a}$

\section{Cases on Appeal after Ex Parte No. io4, Part II}

The report handed down by the commission in Ex Parte No. IO4, Part II, worked a pronounced change in the attitude taken by the Supreme Court on appeals from decisions of the commission. Whereas, prior to the investigation, the Supreme Court had almost unqualifiedly held that the commission was without power, in any case, to prohibit the payment of the Section I5 (I3) allowances that federal tribunal began to shift gradually to the position that if the findings of the commission were based on evidence, they would not disturb those findings. This meant that in any case in which the commission found, upon sufficient evidence, that the charges for spotting services were not included in the district rates, as it apparently did in over seventy per cent of the

65. Associated Jobbers of Los Angeles, I8 I. C. C. 310, 323 (Igro). the case.

65a. It is to be noted that I. C. C. Commissioner Aitchison did not participate in 
cases investigated in Ex Parte No. I04, Part II, the courts would uphold the commission's ruling that no allowances from carrier to shipper should be permitted. The cases following are illustrative of the marked departure from the stand previously taken.

One glass and four steel manufacturing companies petitioned the District Court for Western Pennsylvania to reverse the commission's cease-and-desist order, which called for discontinuance of payment of Section $I_{5}$ ( $\mathrm{I}_{3}$ ) allowances to them for performance of the spotting services. The petitioners, including the heretofore mentioned Allegheny Steel Company, all operated manufacturing plants in Pennsylvania, with a few exceptions. The Pennsylvania commission, following precedents of the Interstate Commerce Commission and the United States Supreme Court, had theretofore held, in regard to intra-state traffic, that the placing of cars at customary points for loading or unloading within the plant industry was a terminal transportation service. $^{66}$

The federal district court decreed that the order be set aside, since the commission had exceeded its statutory powers in issuing it. ${ }^{67}$ The court concluded, as a matter of law: (a) that the placement of cars at places reasonably convenient and accessible for loading and unloading within industrial plants, including those of the petitioners, was a common carrier service to which shippers were entitled, and which the carriers were in duty bound to perform; (b) that the carriers might perform this spotting service themselves, or engage the shippers to do it, paying therefor a reasonable compensation out of their freight rates, without violating the law; (c) that such allowances to shippers, when provided in the carriers' published tariffs, could not be considered as a rebate or a violation of Section 6 of the Interstate Commerce Act; (d) that these allowances might not be condemned simply because they benefited shippers as well as carriers; (e) that the prohibition of allowances for spotting services was beyond the power of the commission; and (f) that in order to support a cease-and-desist order, the commission must make the necessary quasi-judicial findings of fact, findings that the rate or practice complained of was unreasonable, unjustly preferential, unduly discriminatory, or otherwise unlawful; for if it does not, the order is void.

66. National Tube Co. v. Baltimore \& Ohio R. R., r9I9C P. U. R. 4I8 (I9I9).

67. American Sheet and Tin Plate Co. v. United States, I5 F. Supp. 7TI (W. D. $\mathrm{Pa}$. I936). The Supreme Court had theretofore invalidated orders of the commission because of its failure to make adequate findings of fact: United States v. Chicago, $M$., St. P. \& P. R. R., 294 U. S. 499 (I935) ; United States v. Baltimore \& Ohio R. R., 293 U. S. 454 (I935); Florida v. United States, 282 U. S. I94 (I93I). See Atchison, T. \& S. F. Ry. v. United States, 295 U. S. 193 (I935). In a recent case, decided March 3I, I947, the Supreme Court set aside a commission order for want of adequate findings: I. C. C. v. Mechling et al., 67 Sup. Ct. 894 (I947). 
When the government appealed to the Supreme Court, all the carriers, which served the various plants of the petitioners, urged upon briefs: (I) that the spotting service involved was not in excess of team track or simple switching movement; (2) that there was no interference or interruption arising from the desires of the industries or disabilities of their plants sufficient to warrant the commission in condemning the spotting services where performed; (3) that the spotting services at these plants were, by custom, included in the line haul rates; and (4) that the payment of allowances to cover spotting services or their performance by the railroads was in conformity with the efficient and economical management contemplated by the Interstate Commerce Act. Justice Cardozo, who had written the opinion for the Court of Appeals of New York in the General Electric case, ${ }^{68}$ concurred in the Supreme Court's opinion written by Justice Roberts. ${ }^{69}$ After citing numerous precedents upon which the federal court had relied, Justice Roberts placed greater reliance on (a) the General Electric case, ${ }^{70}$ which had been decided on an issue not raised in the pleadings, (b) the Crane Iron Works case, ${ }^{71}$ unlawfully decided by the Commerce Court, and (c) the opinion of the Court of Appeals in the General Electric case, supra. This last opinion had never theretofore been cited as a precedent by the Interstate Commerce Commission or by a federal court, except in one instance ${ }^{72}$ when the commission's cease-and-desist order was enjoined for the reason that the matter had also been decided on an issue not raised in the pleadings; ${ }^{\mathbf{7 3}}$ there the commission itself reversed its original order upon rehearing. ${ }^{74}$

In the American Sheet and Tin Plate case, supra, the Supreme Court finally concluded that in every instance the commission had found, "upon sufficient evidence, that the cars were, in the first instance, placed upon lead tracks, interchange tracks or sidings and subsequently spotted from these tracks; in each instance the spotting service involved one or more operations in addition to the placing of the car on interchange tracks, such as moving it to plant scales for weighing, or some additional burden, such as conformance to the convenience of the plant, supply of special motive power required by the plant's layout or trackage or some other element which called for excessive service greater

68. New York Central \& H. R. R. R. v. General Electric Co., 2Ig N. Y. 22\%, Ir4 N. E. II5 (IgI6).

69. United States v. American Sheet and Tin Plate Co., 30r U. S. 402 (I937).

70. General Electric Co., I4 I. C. C. 237 (1908) ; see Car Spotting Charges, 34 I. C. C. 609, 6I7 (1915).

71. Bureau of Admintstration, Interstate Comarerce Cases in Federal Courts 55 (1927).

72. The Lake Terminal Case, 50 I. C. C. 489 (IgI8).

73. National Tube Co. v. United States, 272 Fed. 735 (N. D. Ohio rgr8).

74. National Tube Co., 55 I. C. C. 469 (rgrg). 
than that involved in team track spotting or spotting on an ordinary industrial siding or spur. We are unable to say that the findings in respect of the individual plants lacked support in the evidence. We are, therefore, bound to accept them and to hold the orders lawful."

Justice Butler dissented, stating he was "of the opinion that the Commission's ruling that the carrier's service of transportation is complete upon delivery to the Industry's tracks is not supported by the circumstantial facts or by the evidence; that the orders here involved are based upon a misconstruction of the Act, and that the decrees of the District Court should be affirmed." (p. 44I et seq.)

In the petition for rehearing, which was denied, the appellees alleged, inter alia: "We readily concede that if there is some evidence to sustain the Commission's findings, this court will not disturb them. But here there is no such evidence. Insofar as concerns that section of the United States in which Appellees' plants are located, we assert unqualifiedly in our brief in this court (pages 20-24) that the undisputed testimony was to the effect that the established freight rates included the spotting service, and we challenge the Appellants at the oral argument before your Honorable Court, as had been done before in the court below, to point to any substantial evidence in the record which would sustain the conclusions of the Commission in this regard. Not a particle of such evidence was referred to in substantiation of the conclusions of the Commission. . . .

"We are confident in asserting the proposition that the railroads in a particular section of the country may publish and maintain schedules of rates over a period of years which they and the shippers on their lines interpret as including a particular terminal service, and that such an interpretation by the parties to the contract over a long period of years will have the force of law."

In the Pan American Petroleum case, ${ }^{75}$ the federal statutory court enjoined the commission's order to discontinue payment of allowances to a number of manufacturing companies for performing spotting service, on the ground that the order was not supported by substantial evidence. The court said: "We think it clear that the railroads involved are required, under the law, to perform such service as a part of transportation." The Supreme Court held, however, that the order was based on substantial evidence and should not have been set aside. ${ }^{76}$

Six years later, a case involving the Celotex Company, one of the plaintiffs in the Pan American Petroleum case, supra, came before Division 3 of the commission (Alldredge, Mahaffie, and Johnson) and it

75. Pan American Petroleum Corp. v. United States, I8 F. Supp. 624 (E. D. La., S. D. Tex. 1937).

76. United States v. Pan American Petroleum Corp., 304 U. S. 156 (1938). 
was held that the switching service to and from the point of loading and unloading beyond the interchange points was a service which was contemplated under the so-called line haul rates. ${ }^{77}$

The Standard Oil Company of Louisiana, another plaintiff in the Pan American Petroleum case, was involved in a case eleven years later embodying similar facts, and the commission decided that such spotting service was included in the rates of the rail carriers. ${ }^{78}$

In Koppers Gas \& Coke Co., the District Court for the District of Minnesota, in the absence of a complete record of the evidence upon which the commission had based its report, held that it did not have the power to question the commission's finding of fact. The court later dismissed the petition, relying mainly upon the once-cited decision of the Court of Appeals of New York in the General Electric case, supra, with Justice Sanborn writing a strong dissenting opinion, in which he insisted that "the order of the Commission should be enjoined for the sole reason that the evidentiary base on which it rests is too weak to support it."

Following the decision in the Tin Plate case, supra, the District Court for the Western District of New York upheld the findings of the commission in the Hanna Furnace Corporation case. ${ }^{80}$ Judge Burke, notwithstanding the prior decision of the Supreme Court in the matter of factual findings, vigorously dissented, ${ }^{81}$ saying: "I think the Commission's findings that the car spotting, if conducted by the railroads, would be marked by frequent delays, occasionally by intraplant switching, is not supported by substantial evidence, and is contrary to the only evidence on the subject in the case, and as such is beyond the powers of the Commission." He cited Interstate Commerce Commission v. Louisville \& Nashville R. R.: ${ }^{82}$

"A finding without evidence is arbitrary and useless, and an act of Congress granting authority to anybody to make a finding without evidence would be inconsistent with justice and an exercise of arbitrary power condemned by the Constitution."

77. Celotex Co. Terminal Allowance, 245 I. C. C. I05 (I94I).

78. Standard Oil Co. of Louisiana Terminal Allowance, 266 I. C. C. 437 (I946). See also Union Tank Company, decided April I5, 1947-upon reargument respondents' practices relating to the switching of carload freight and privately owned empty tank cars of the Car Company at North Baton Rouge, La., found not unlawful, reversing prior report 264 I. C. C. 479 (1946), wherein Division 3 of the commission had found in substance that respondents' rates, characterized as line haul rates, did not include the industrial switching services under discussion.

79. Koppers Gas \& Coke Co. v. United States, II F. Supp. 467 (D. Minn. I935).

So. Hanna Furnace Corp. Terminal Allowance, 253 I. C. C. 6r3 (I942). 1943).

81. Hanna Furnace Corp. v. United States, 53 F. Supp. 34I, 348 (W. D. N. Y.

82. 227 U. S. 88 (1913). 
In the Staley case, ${ }^{83}$ decided June Io, I943, the District Court for the Southern District of Illinois held that the commission's findings, that spotting services within the plant area of manufacture were in excess of services rendered shippers generally, and that performance of such services free of charges would be unlawful, were not sustained by the evidence. The court further held that the commission's finding of undue preference was also not supported by evidence. When the case was appealed to the Supreme Court, Chief Justice Stone, who wrote the opinion, noted: "The principal question for our decision is whether, as the District Court thought, the order is invalidated because it results in a prohibited discrimination." In other words, was the Staley case under Section 6 (7) or under Sections 2 and 3 ? That phase of the matter has been discussed heretofore, and need not be mentioned further, save to say in passing that the curious finding that Section 6 (7) has been violated in the circumstances of these various car spotting cases is difficult to comprehend. ${ }^{84}$

\section{Federal Administrative Procedure Act}

For more than ten years prior to I946, legislation to consolidate and improve administrative procedure had been under consideration by both executive and legislative departments of the government. A significant landmark in the series of investigations which led eventually to the passage of the Administrative Procedure Act of $1946^{85}$ was the I937 Report of the President's Committee on Administrative Management, which the late President Roosevelt called "a great document of permanent importance" when he transmitted it to Congress. At the same time, Mr. Roosevelt took occasion to remark that the practice of creating administrative agencies "who perform work in addition to judicial work, threatens to develop a 'fourth branch' of the Government for which there is no sanction in the Constitution." 86 The committee augmented the president's statements by declaring that, in a system where commissioners in such agencies were forced to serve both as prosecutors and as judges, the inevitable result must be an undermining of judicial fairness and a weakening of public confidence in that fairness. It was toward amelioration of the process of judicial review of the

83. Wabash R. R. v. United States, 5 I F. Supp. I4I (S. D. I1l. I943).

84. United States v. Wabash R. R., 321 U. S. 403 (I944), rehearing denied, 322 U. S. Ig8 (I944). In the Staley case, ibid., upon rehearing, 266 I. C. C. 213 (1946), the suspended schedules providing for placement of cars at elevator $C$ of the Staley plant, without the addition of a spotting charge, were found to be just and reasonable.

85. Pub. L. No. 404, 79th Cong., 2d Sess. (June II, I946).

86. Report of the Committee on the Judiciary, House of Representatives, on S. 7 -A Bill to Improve the Administration of Justice by Prescribing Fair Administrative Procedure, H. R. Rep. No. I980, 79th Cong., 2d Sess. 7 (May 3, I946). 
decisions of the commissions that the Administrative Procedure Act was directed.

Section 7 (c) of the act deals with the subject of evidence requirements in a hearing before an administrative agency, and begins: " $\mathrm{Ex}-$ cept as statutes otherwise provide, the proponent of a rule or order shall have the burden of proof." It also declares that no rule or order shall be issued by the agency, "except upon consideration of the whole record ... as supported by and in accordance with the reliable, probative, and substantial evidence."

Section ro (e) deals with the aforementioned important subject of judicial review, and provides, inter alia, that one of the grounds for holding the findings of an agency unlawful shall be that such findings were "unsupported by substantial evidence," as required by Section 7 (c) supra. What is meant by "substantial evidence" may be gleaned from the floor discussions preceding the unanimous passage of the act by the Senate. In those discussions it was decided that something more than a mere scintilla of evidence would be necessary as a basis for an agency's decision that would not be subject to reversal upon judicial review. Hearsay was also regarded as insufficient to meet the standard of "probative" evidence. ${ }^{87}$

As far as the Interstate Commerce Commission is concerned, its procedure as an administrative agency was not fundamentally changed by the Administrative Procedure Act, except insofar as the Interstate Commerce Act had failed to prescribe the scope of judicial review. ${ }^{88}$ The commission and its practitioners are to be congratulated upon the fact that there was never raised a single substantial complaint against the commission's procedure. In view of this latter situation, it is easy to see why the commission asked to be exempted from the provisions of the Administrative Procedure Act on the theory that the diversified functions of that body would be rendered more uncertain thereby. This request was, however, denied by Congress, and it is unlikely that the commission's effectiveness has suffered or will suffer as a result of its subjection to the act.

In conclusion, it should be stated, until the courts provide further definitions and directions, the most that can be expected in Interstate Commerce Commission procedure is the application of sound judgment with a sense of fairness.

The report of Officer Bartel in Ex parte No. I04, Part II, was apparently not wholly satisfactory to the commission, as borne out by the

87. 92 Cong. Rec. 2 I99 (March 12, 1946).

88. Sen. Rep. No. 442, 76th Cong., ist Sess. Io (I939). See Dickinson, Admin istrative Procedure Act: Scope and Grounds of Broadened Judicial Review, 33 A. B. A. J. 434 (1947). 
fact that instead of adopting a single omnibus report, the commission ordered each of the individual cases to be disposed of by individual reports based on the particular facts in each of the cases. Although this is a long procedure, it has resulted in a modification of certain earlier findings, with the end result that the facts later presented justified the conclusion that spotting services may fairly be regarded as included in the carriers' rates.

Without the Administrative Procedure Act, if a mere scintilla of evidence would be sufficient ground on which to base a decision, and the facts were not clearly ascertained by competent, credible, and substantial evidence, then, as so aptly stated by William Morris Meredith, of the old Bar of Philadelphia, the event of administrative litigation "would indeed almost always be uncertain." 